an exodus of faculty from higher education in the near future? Will the quality of academic work suffer? Care should be taken to monitor these developments and turn national attention toward assessing their implications for the continued and future "relevance" of the national higher education system, in general, and of the academic profession, in particular.

\section{The Decline of Private Higher Education: A Special Section}

One of the key trends in international higher education, the rapid expansion of the private sector now holds one-third of all global enrollments. However, the growth is not unbroken or inexorable and sometimes stalls and even reverses. This special section on the decline of private higher education seeks to identify the major dynamics (including causes) of private higher education decline. Certain dynamics may have the greatest effect in a given world region or country. Sometimes we see multiple or inter-related factors within a country. In any event, dynamics such as public expansion, elevation of educational institutions to higher education status, demographic stagnation, and privatization within public higher education institutions have reversed the private higher education proportional growth in various countries.

Yet, to debate the dynamics of private higher education decline it is relevant to evaluate the shape and weight of decline. A country may experience decline in different private subsectors whether or not there is decline in the private sector overall. Declines may constitute steep or slight, temporary or long-lasting procedures. The pieces in this special section show that private higher education decline can be a noteworthy reality alongside the much-larger reality of private higher education growth. This special IHE section is coordinated by Joanna Musial, a doctoral research associate in PROPHE, University at Albany, SUNY. E-mail: jm684672@albany.edu.

The Program for Research on Private Higher Education (PROPHE) contributes an article on private higher education in each IHE issue. For this issue, however, PROPHE collaborates with a special section on the Decline of Private Higher Education.

\section{An International Exploration of Decline}

\section{Daniel C. Levy}

Daniel C. Levy is a Distinguished Professor at the University at Albany, State University of New York, and is director of the Program for Research on Private Higher Education. E-mail: dlevy@uamail. albany.edu.

$\mathrm{G}$ rowth has rightly formed a dominant theme in the study of private higher education, and expansion continues mostly unabated. However, the decline of private higher education constitutes an untold reality, and growth is not a uniform, omnipresent, or inevitable course. History even records private higher education abolition. Less radically, various types of private higher education declines occur even while private numbers usually grow-a more common phenomenon on the public side in recent decades.

Reasons for private higher education decline can be categorized in two broad categories-(I) social and (2) political or public-sector policies.

\section{SOCIAL FACTORS}

The decline of private higher education is seriously caused by the lapse of social identity and distinctiveness that previously fueled private growth. The weakening of Catholic identity in the Americas is a prominent case in point. The distinctive Catholic orientation has become less defining even at private institutions that remain officially Catholic. Fewer families choose private education on religious grounds. Similarly, as mainstream society becomes more open mainstream to young women, fewer families choose private education on gender grounds.

A different socially based decline is demographically induced, as a population shift comes to affect overall demand for higher education. The demographic shift could, most dramatically, produce in higher education an actual fall or at least a reversal of strong growth. Such a basis of private higher education decrease is not common in the developing world, while there are cases (see the article on Thailand in this special section) and it is a powerful factor in the developed world. Demographic decline has not affected western European private higher education much, since private higher education is still a small sector in most countries. Yet, in Portugal, the country with the largest private higher education sector, that share fell from 36 to 25 percent, from 1996 to 2006 . Some programs no longer attract applicants, and some private higher education institutions have faced deaths or at least mergers. Eastern Europe has much higher shares of private higher education, and thus the sector is more vulnerable to demographic decline. 